\title{
Cinética de degradação e determinação quimiométrica de azocorante durante processo Fenton-type.
}

\section{William B. Nunes*, Renato F. Dantas, Enelton Fagnani.}

\section{Resumo}

Esse projeto objetiva a determinação da concentração do azocorante vermelho de metila (VM) presente em um efluente contendo outras substâncias coloridas (ferroína e azul de metileno - AM), durante a sua degradação por um processo oxidativo avançado (POA) definido como Fenton-type; de posse dos valores de concentração em função do tempo de degradação, estudos cinéticos serão conduzidos.

Palavras-chave: Análise multivariada; contaminantes emergentes; processos oxidativos avançados;

\section{Introdução}

Azocorantes são contaminantes ambientais recalcitrantes de difícil degradação microbiológica ${ }^{[1]} \mathrm{e}$ são vastamente utilizados em várias indústrias. Neste contexto, surgem os processos oxidativos avançados (POA) como uma alternativa ao tratamento de tais substâncias, com destaque aos processos baseados na reação de Fenton ${ }^{[2]}$. O presente projeto propõe uma metodologia para avaliar a eficiência de degradação de vermelho de metila na presença de outras substâncias coloridas, utilizando-se espectrofotometria e ferramentas quimiométricas.

\section{Resultados e Discussão}

A fim de descobrir a real concentração de corante presente na solução para assim medir a eficiência de degradação, foi proposta a metodologia da gravimetria. Entretanto, enfrentou-se dificuldades de quantificação devido à baixa concentração encontrada em um volume de $5 \mathrm{~mL}$.

Assim, na tentativa de melhorar os resultados, foi proposta uma mudança na metodologia acima, em que triplicaria o volume final de solução no pesa-filtro. Na Tabela 1, o resultado desta proposta é apresentado.

Tabela 1. Concentrações dos corantes pelo novo método proposto de Gravimetria.

\begin{tabular}{cc}
\hline $\begin{array}{c}\text { Média das Concentrações de } \\
\text { Azul de Metileno (mg/L) }\end{array}$ & $\begin{array}{c}\text { Média das Concentrações de } \\
\text { Vermelho de Metila (mg/L) }\end{array}$ \\
\hline 3000 & 2780 \\
2800 & 2300 \\
2800 & 2460 \\
\hline
\end{tabular}

Após obter estes dados, é possível iniciar a realização da próxima metodologia proposta no projeto, a espectrofotometria derivativa, e assim traçar uma curva padrão para essas substâncias. Optou-se por utilizar a absorbância de padrões das três substâncias envolvidas: ferroína, AM e VM, no intervalo de comprimento de onda entre 300 e 750 $\mathrm{nm}$.

Figura 1. Derivadas dos padrões mais concentrados das três substâncias em estudo

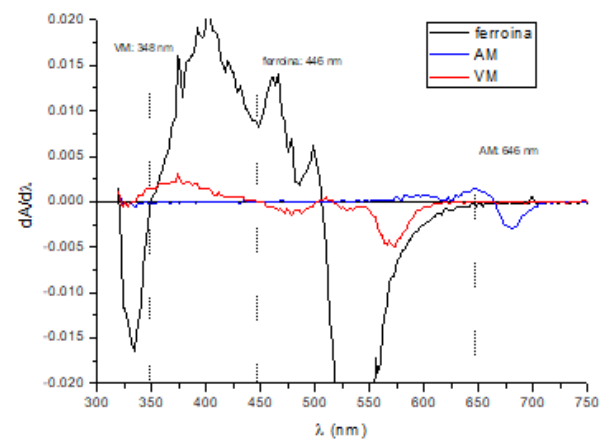

Por fim, é possível identificar pela Figura 1 ao menos um comprimento de onda útil para cada substância, sendo eles: $348 \mathrm{~nm}$ para VM, $446 \mathrm{~nm}$ para ferroína e $646 \mathrm{~nm}$ para AM. Assim, podem-se traçar curvas analíticas para cada uma das substâncias baseando-se nestes comprimentos, e quantificá-las mesmo em presença das demais. Entretanto, ao traçar essas curvas para AM e VM, ambas apresentaram valores de $r^{2}$ muito baixos para fins analíticos.

\section{Conclusões}

A espectrofotometria derivativa apresentou potencialidades interessantes como metodologia de quantificação de corantes, porém não pode ser utilizada quando se tem como limitação concentrações tão baixas quanto às utilizadas neste estudo.

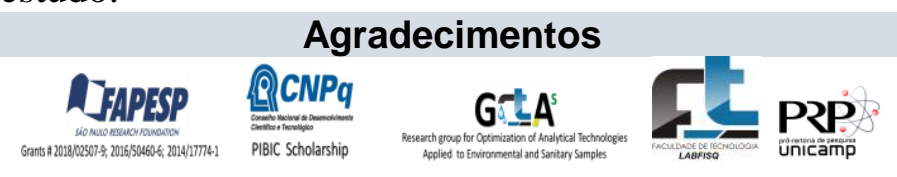

${ }^{[1]}$ N.Ertugay, F.N. Acar, Arabian J. Chem. 10 (2017) S1158.

${ }^{[2]}$ A. De Luca, R.F. Dantas, S. Esplugas, Water Res. 61 (2014) 232. 